\title{
RESIDÊNCIA PEDAGÓGICA: ABRINDO CAMINHOS EPISTEMOLÓGICOS NA TEORIA E PRÁTICA NO COLEGIO ESTADUAL PROFESSORA IRANY NUNES DO PRADO
}

Pedagogical residence: opening epistemological pathways in theory and practice in State School Teacher Irany Nunes do Prado

Residencia pedagógica: apertura de los caminos epistemológicos en teoría y práctica en la Escuela Estatal Professora Irany Nunes do Prado

Aparecida de Jesus Soares Pereira ${ }^{* 1}$, Waldir Pereira da Silva ${ }^{1}$, Valdivino Nére dos Reis ${ }^{1}$, Lidiane Barbosa Dias ${ }^{1}$, Francislene Souza dos Santos ${ }^{1}$

${ }^{1}$ Laboratório de Educação Musical, Curso de Licenciatura em Educação do Campo, Universidade Federal do Tocantins Arraias, Brasil.

*Correspondência: Curso de Licenciatura em Educação do Campo, Universidade Federal do Tocantins, Campus Professor Dr. Sérgio Jacintho Leonor, Av. Juraíldes de Sena e Abreu, Setor Buritizinho/ sala 10 - Bloco Bala, Arraias - Tocantins, Brasil.CEP:77.330-000.e-mails: cida.soares@uft.edu.br

\section{Artigo recebido em 09/04/2020 aprovado em 16/04/2020 publicado em 18/04/2020.}

\section{INTRODUÇÃO}

Este relato de experiência tem como proposta descrever as experiências didático-pedagógicas enquanto residentes do Programa Residência Pedagógica da Universidade Federal do Tocantins, Campus Arraias/TO, tendo como objetivo o ensino e a aprendizagem, a vivência, a interpretação e contextualização das Artes Visuais e da Música como elementos aglutinadores na educação básica de escolas públicas campesinas.

O Residência Pedagógica (RP) é um programa implantado pela CAPES (Coordenação de Aperfeiçoamento de Pessoal de Nível Superior) que visa a ampliação do conhecimento discente, sua interação e integração na sala de aula dando ênfase na diversidade cultural.

A implantação do RP no Curso de Licenciatura em Educação do Campo/ Campus Arraias, tem como finalidade consolidar competências e habilidades para a docência, na "Educação Musical e nas Artes Visuais", tendo como foco contribuir para a formação integral dos discentes nas escolas campesinas, com base numa fundamentação interdisciplinar, que sejam capazes de investigar, pensar, compreender e recriar a realidade. Assim sendo, o Subprojeto do Curso de Licenciatura em Educação do Campo - Códigos e Linguagens Artes Visuais e Música, se apresenta como uma alternativa eficaz para a formação de professores e inserção do ensino de Artes Visuais e Música nas escolas do campo. Entende-se que é um trabalho colaborativo envolvendo e integrando a Instituição de Ensino Superior e as Escolas de Educação Básica, estabelecendo o tripé: Universidade, Estágio e Escolas, contemplando também o tripé Ensino, pesquisa e extensão.

Os trabalhos realizados nas intervenções em sala de aula, envolvem os conteúdos de Artes em um contexto multicultural teórico e prático; no aprender e no ensinar, no vivenciar, no interpretar e contextualizar a identidade artística das comunidades de origem dos alunos, consolidando competências e habilidades, troca de saberes na perspectiva da arte como um elemento de 
inclusão e emancipação do sujeito a partir da consolidação do conhecimento. Por isso, de acordo com (GONDIM; MÓL, 2009, p. 2), a instituição de ensino deve ser "o local de mediação entre a teoria e a prática, o ideal e o real, o científico e o cotidiano". Dessa forma o Subprojeto Educação do Campo Artes Visuais e Música é um complemento para a formação docente, uma preparação, um estágio, que tem como enfoque à docência, objetivando também a inserção desse ensino e aprendizagem na educação básica nas escolas do campo.

\section{METODOLOGIAS E MATERIAIS}

O Programa Residência Pedagógica funciona como um complemento teórico-prático na formação docente, uma vez que, proporciona ao estudante um aprendizado das atividades profissionais, levando-o a descobrir e a compreender os diferentes desafios encontrados na profissão.

O Colégio Estadual Professora Irany Nunes do Prado, situado à Praça da Capela de Nossa Senhora Aparecida, Distrito Prata, Município de Monte Alegre de Goiás oferta o Ensino Fundamental ( $6^{\circ}$ ao $9^{\circ}$ Ano), Ensino Médio e EJA (2 ${ }^{\mathrm{a}}$ etapa e Ensino Médio).

Faz-se necessário enfatizar a importância dos processos metodológicos que foram abordados antes das idas à escola, as reuniões promovidas pela Coordenadora com a participação das preceptoras e residentes, o trabalho de campo para levantamento de informações, assim como o planejamentos das aulas e projetos a serem desenvolvidos nas escolas campo.

Dando início às atividades do Residência, primeiramente foi feita a caracterização do Colégio, a observação das aulas ministradas pela professora regente da disciplina Artes, e em seguida a intervenção com a aplicação dos planejamentos de aulas e desenvolvimento de projetos na área específica, conjuntamente com os professores orientadores e as preceptoras do RP.

No contexto da Residência Pedagógica os acadêmicos vivenciam experiências problematizadoras que ressignificam o fazer pedagógico, abordando diferentes situações do cotidiano escolar, tratando das especificidades da educação voltadas para a formação de um docente apto, ético, democrático e capaz de refletir sobre sua própria ação educativa. Assim, "o papel da educação é o de formar sujeitos críticos, capazes de construir outro projeto de desenvolvimento do campo e de nação" (FIGUEIREDO, 2011 p. 166). Neste sentido os acadêmicos socializam os estudos teóricos e têm a oportunidade de realizar ações práticas por meio de projetos, estágios, dentre outras atividades que possam experimentar a prática educativa como um recurso didático para o conhecimento e emancipação do indivíduo.

Os autores Pereira; Silva (2019, p. 8.354), afirmam que "os processos de ensino/aprendizagem nos contextos dos saberes e práticas tradicionais com os saberes construídos na academia são de fundamental importância no processo educacional'. Dessa forma, o fazer pedagógico é uma ação que requer o desenvolvimento de competências e saberes que possam oferecer aos discentes a capacidade de refletir sobre suas experiências, construir novos saberes seja no campo das Artes, seu objeto de estudo, suas vivências culturais, ou em outras áreas do conhecimento.

Durante a vigência do Programa os residentes são acompanhados pela preceptora e coordenadora, que fazem acompanhamento de frequências, relatórios mensais, assim como cumprir a carga horária definida pelo Programa. 


\section{RESULTADOS E DISCUSSÃO}

O Programa Residência Pedagógica é uma alternativa na formação discente, dando-os subsídios através de uma fundamentação teórica, vivência, experiência no ensino e na aprendizagem, a partir de sua inserção nas comunidades e escolas. Desse modo, a perspectiva desse convívio é a integração, a interação e a inclusão social como um todo, respeitando a diversidade e a particularidade de cada aluno, levando em consideração a sua realidade e sua identidade cultural.

\section{CONCLUSÃO}

O Subprojeto Residência Pedagógica é muito importante e relevante na formação acadêmica. Assim, as atividades desenvolvidas contribuem de forma positiva na complementação dos conhecimentos adquiridos, no ensino e aprendizagem como futuros educadores de Artes Visuais e Música. O RP traz vantagens principalmente porque proporciona nas intervenções, a aplicação de conteúdo específico de Artes Visuais e Música aos alunos, dando oportunidades para desenvolver habilidades artísticas tais como: concentração, criatividade e coordenação motora, dentre outras. Dessa forma, o ensino e aprendizagem vivenciada no RP é uma base na vivência docente, é um processo de ensinar e ao mesmo tempo de aprender e de multiplicar saberes, com enfoque epistemológico na formação de sujeitos críticos emancipados. Percebe-se também que com essa relação mais estreita entre escolas campo e universidade a formação docente também segue fortalecida.

\section{AGRADECIMENTOS}

Agradecimento a CAPES pelo incentivo financeiro. À UFT por tornar possível a realização do Programa Residência Pedagógica e pelo uso de laboratórios e/ou empréstimo de equipamentos, ao Curso de Licenciatura em Educação do Campo da UFT, às escolas parceiras e Secretaria de Educação.

Todos os autores declararam não haver qualquer potencial conflito de interesses referente a este artigo.

\section{REFERÊNCIAS}

CAPES. Portaria Gab. $n^{\circ} 38$, de 28 de fevereiro de 2018. Institui o Programa de Residência Pedagógica. Disponível em: http://www.capes.gov.br/educacao- asica/programaresidência-pedagógica. Acesso em: 01 de março de 2019.

FIGUEIREDO, Luiz Carlos Oliveira de. Análise da produção científica na área da educação física sobre a educação do campo. V Colóquio Internacional de Políticas Públicas e Práticas Curriculares. GT 09: Políticas de Currículo e a Educação do Campo, 2011.

GONDIM, M. S. C.; MÓL, G.S. Interlocução entre os saberes: relações entre os saberes populares de artesãs do triângulo mineiro e o ensino de ciências. In: Encontro Nacional de Pesquisa em Educação em Ciências, 7., 2009, Florianópolis. Anais... Florianópolis, 2009.

PEREIRA, Aparecida de Jesus Soares; SILVA, Waldir Pereira da. Curso de licenciatura em educação do campo em Arraias/TO: formação musical e profissionalidade docente. Brazilian Journal of Development, Curitiba, v. 5, n. 7, p. 8352-8365 jul. 2019 ISSN 2525-8761. 